bibliografii w tych dysertacjach, które o alegorezie w pismach pisarzy aleksandryjskich będą choćby tylko wspominać.

W trakcie jej lektury nasuwa się wiele myśli związanych $\mathrm{z}$ bardzo aktualnymi we wczesnym chrześcijaństwie koncepcjami eschatologicznymi, pobudzanymi przez Pismo św., a zwłaszcza Apokalipsę (ale nie tylko). Płodność tych doktryn była niemała, także i u późniejszych pisarzy dostrzegalna, choć niekoniecznie bezpośrednio wyrażana.

Książka ks. Mariusza Szrama, będąca rozprawą habilitacyjną, spełniła nie tylko wymagania stawiane jej jako rozprawie, ale zasługuje w pełni na to, by znaleźć się w rękach czytelników, którzy nie pracują naukowo na tym polu, lecz chcą pogłębić swą wiedzę z zakresu literatury wczesnochrześcijańskiej, a ich zainteresowania sięgają nieco głębiej; po jej przeczytaniu wiedza ta może okazać się przydatna także na terenie ich własnej działalności. Niewielki nakład pracy, jak zwykle uwarunkowany względami finansowymi, może zatem okazać się niewystarczający.

Jerzy Wojtczak-Szyszkowski - Warszawa

\title{
BAZIL VELKÝ, Listy II. Hexaémeron, preložil, úvodnú štúdiu a vysvetlivky napísal a registre zostavil Daniel Škoviera, Bibliotheca Antiqua Christiana 2, Prešov 2002, Náboženské vydavatelstvo PETRA, ss. 295 + nlb. 1 + mapa 1.
}

Oczekiwany przez czytelników kolejny tom słowackiej patrystycznej serii wydawniczej „Bibliotheca Antiqua Christiana” ukazal się w polowie 2002 roku. Podobnie jak pierwszy, tak i jej drugi tom ma dwuczęściową strukturę treściowo-wydawniczą. Pierwsza część tego drugiego tomu serii, zawierająca Listy z lat 375-378, oznaczone liczbą 193-334, jest kontynuacją epistolograficznego dorobku Bazylego Wielkiego. Druga część tomu, której zawartość stanowi dziewięć homilii Hexaémeronu, albo homilii o dziele stworzenia w sześciu dniach ${ }^{1}$, ukazuje fragment kaznodziejskiego dorobku tegoż wielkiego Ojca Kościoła z Cezarei Kapadockiej.

W nocie edytorskiej (s. 293) charakteryzującej całościowo strukturę wydanego tomu, thumacz wracając do historii przekładu Listów oraz ich konspiracyjnego wydania i upowszechnienia podczas totalitarnego prześladowania na Słowacji (1948-1989), przyznaje, że był świadom braków swojego dzieła. Wszystkie je usunął dopiero w związku z przyjęciem propozycji opublikowania Listów w serii „Bibliotheca Antiqua Christiana”. Wskazując na krytyczne wydanie greckiego tekstu $\mathrm{Y}$. Courtonne'a ${ }^{2}$ stanowiącego podstawę pracy tłu-

\footnotetext{
${ }^{1}$ Por. Sv. Bazil Velky, Hexaémeron ciže Homilie o diele Siestich dni, ss. 179-282.

${ }^{2}$ Por. Saint Basile, Lettres, éd. Yves Courtonne, II-III, Paris 1961 I 1966, Les Belles Lettres.
} 
macza, Autor informuje czytelników, że wśród listów tego słowackiego przekładu nie ma, skądinąd interesującej, ale apokryficznej korespondencji Bazylego Wielkiego. Do tej zaś grupy Listów należą: korespondencja z retorem Libaniuszem (Ep. 335-359), Julianem Apostatą (Ep. 360), Apolinarym (Ep. 361-364), cesarzem Teodozjuszem Wielkim ( $E p$ 365) i mnichem Urbikonem (Ep. 366).

W tej samej nocie wydawniczej thumacz przyznaje, że przekład Hexaémero$n u$ przygotował wyłącznie dla serii wydawniczej „Bibliotheca Antiqua Christiana", tłumaczenia zaś dokonal z 2. wydania tekstu krytycznego S. Gieta, wydanego w „Sources Chrétiennes”, ${ }^{3}$. Dodaje również, że św. Bazyli w swoich homiliach przy cytowaniu i komentowaniu Starego Testamentu używał Septuaginty i oryginału Nowego Testamentu. Czytelnik słowacki otrzymał przez to od thmacza wyjaśnienie, że wprowadzone przez niego do przekładu cytaty biblijne nie będą wiernie odpowiadały oficjalnemu slowackiemu przekładowi Biblii z 1995 roku $^{4}$. Przez wydanie tego tomu kontynuowanej już serii patrystycznej, czytelnik słowacki dostał dalszą możność, by się zbliżyć i czerpać $\mathrm{z}$ duchowego bogactwa, którym w swoim czasie Ojcowie dzielili się ze współczesnymi.

Tadeusz Leander Pietras OSPPE - Vranov n/Topl'ou, Słowacja

\section{Ks. Norbert WIDOK, Physis w pismach Grzegorza $z$ Nazjanzu. Studium z teologii patrystycznej, Opole 2001, Redakcja Wydawnictw Wydziału Teolo- gicznego UO, ss. 303.}

Wśród pozycji związanych z myślą Ojców Kościoła, jakie ukazały się w ostatnim czasie, $\mathrm{z}$ dużą satysfakcją odnotowujemy te, które wiążą się z tradycją patrystyki greckiej; ta bowiem, mimo wszystko, jest nieco mniej reprezentowana w bibliografii i to nie tylko polskiej, a wpływ na to ma zarówno wielość wątków poruszanej problematyki i nierzadko niejasność wypowiedzi (jak np. w pismach Klemensa Aleksandryjskiego), jak i trudny język; w aktualnej bowiem sytuacji nauka języka greckiego nie znajduje właściwego miejsca nawet na studiach filologicznych, a cóż dopiero teologicznych; ten problem ciągle czeka na pozytywne rozwiązanie, na razie jednak kryzys ulega coraz większemu pogłębieniu. $\mathrm{Z}$ tym większym zainteresowaniem bierzemy do ręki publikacje, które opierają się na źródłach greckich, myślimy tu oczywiście

${ }^{3}$ Basile de Césarée, Homélies sur Hexaéméron, par Stanislas Giet, 2. édition augmentée, SCh 26bis, Paris 1968.

${ }^{4}$ Por. Sväte Písmo Starého i Nového zákona. Slovenský ústav svätého Cyrila a Metoda, Rím 1995. 